\title{
Variation in Pathogenicity and DNA Polymorphism Among Botrytis cinerea Isolates Sampled Inside and Outside a Glasshouse
}

\author{
A. Kerssies and A. I. Bosker-van Zessen, Research Station for Floriculture and Glasshouse Vegetables, P.O. Box \\ 8, 2670 AA Naaldwijk, The Netherlands, and C. A. M. Wagemakers and J. A. L. van Kan, Department of Phyto- \\ pathology, Wageningen Agricultural University, P.O. Box 8025, 6700 EE Wageningen, The Netherlands
}

\begin{abstract}
Kerssies, A., Bosker-van Zessen, A. I., Wagemakers, C. A. M., and van Kan, J. A. L. 1997. Variation in pathogenicity and DNA polymorphism among Botrytis cinerea isolates sampled inside and outside a glasshouse. Plant Dis. 81:781-786.

Colonies of Botrytis cinerea were obtained from spore samplers placed inside and outside a glasshouse with a rose crop. Pure cultures were made from five colonies collected on one sampling date every month throughout the year. These isolates were tested for germination on water agar and for pathogenicity on gerbera and rose petals. The germination rate of the conidia on water agar varied between 60 and $99 \%$. Pathogenicity of the isolates on gerbera and rose flowers ranged from 14 to $166 \%$ relative to reference isolate $\mathrm{Bc} 16$ and varied among isolates collected on the same day as much as among isolates collected in different months. The pathogenicity of the isolates on rose flowers was overall higher than on gerbera flowers. Random amplified polymorphic DNA (RAPD) analysis was performed on 30 selected isolates with different relative pathogenicity, collected both inside and outside the glasshouse. Almost all of the isolates were genetically different. No correlation was found among pathogenicity, sampling time, sampling place, and RAPD patterns. Results are further evidence for the statement that $B$. cinerea inoculum in glasshouses continuously originates from many different sources in their vicinity.
\end{abstract}

The fungus Botrytis cinerea Pers.:Fr., the imperfect stage of Botryotinia fuckeliana (de Bary) Whetz., is a pathogen of a wide variety of economically important plants grown inside and outside glasshouses, such as vegetables, ornamentals, bulbs, and fruits. It is also a saprophyte on senescing and dead plant material. $B$. cinerea is one of the main airborne pathogens in ornamentals grown under glass, where it can cause severe losses $(3,5)$. B . cinerea is one of the fungi most frequently sampled in air $(12,15)$, and it is able to colonize new, uncontaminated glasshouses rapidly. $B$. cinerea causes only postharvest problems in cut flowers grown under glass, while in glasshouses with potted plants or vegetables, it can also cause problems during production (10). The fungus can colonize senescing leaves on a wet soil surface and subsequently sporulate abundantly (2). In vegetables, $B$. cinerea can infect wounds on stems and subsequently invade healthy stems (19).

Conidia, ascospores, mycelial fragments, and sclerotia all contribute to dispersal of $B$. cinerea (7), but only conidia

Corresponding author: A. Kerssies

E-mail: A.Kerssies@PBGN.agro.nl

Accepted for publication 31 March 1997.

Publication no. D-1997-0520-06R

(C) 1997 The American Phytopathological Society are important propagules of $B$. cinerea in Dutch rose glasshouses (10). Spore sampling on a selective medium at one height and at a limited number of locations is adequate for efficient monitoring of $B$. cinerea in glasshouses (9). It was postulated that conidia of $B$. cinerea sampled in a glasshouse originate from sources both inside and outside the glasshouse, because they can easily enter and escape glasshouses (10). Conidia of $B$. cinerea are always present in the glasshouse air, day and night, and throughout the year (10). The horizontal and vertical distribution of conidia of $B$. cinerea in glasshouses is fairly uniform and is independent of the crop grown in the glasshouse $(9,11)$.

The aim of the present study was to investigate the variation in pathogenicity on flowers among isolates of $B$. cinerea sampled inside and outside a glasshouse throughout a year. Genetic variation among the different $B$. cinerea isolates was studied by random amplified polymorphic DNA (RAPD) analysis (17) in order to investigate, on a limited scale, the population structure of the sampled isolates. Since the inoculum was postulated to originate from various sources outside the glasshouse (10), it was assumed that the population inside the glasshouse would be genetically diverse. On the other hand, RAPD analysis would be able to reveal whether certain genotypes dominated in the glasshouse population throughout the growing season, as an indication for the occurrence of epidemics of genetically homogeneous and stable isolates.

\section{MATERIALS AND METHODS}

Isolates. In 1992, colonies of B. cinerea were obtained from spore samplers (8) placed inside and outside a $300 \mathrm{~m}^{2}$ glasshouse with a rose crop, cv. Sonia (11). This glasshouse is the last in a row of four glasshouses of $300 \mathrm{~m}^{2}$. In the neighboring glasshouse (west of our glasshouse), roses were also grown. In the near vicinity, in the other three directions from the glasshouse, there were no glasshouses; but small trees (east of the glasshouse), grass (north of the glasshouse), and cut flowers (south of the glasshouse) were grown. The prevailing winds in the neighborhood of the glasshouse were northwest. The four glasshouses are part of a complex of glasshouses of the Research Station for Floriculture and Glasshouse Vegetables of approximately $15,000 \mathrm{~m}^{2}$ scattered over an area of approximately 22,000 m². In 1992 in these glasshouses, all kinds of ornamental crops were grown: gerberas, roses, bouvardias, carnations, saintpaulias, spathiphyllums, cyclamen, begonias, pelargoniums, and so on. In all these crops, B. cinerea can be a problem.

Every week, fresh samplers with a selective Botrytis medium (8) were kept inside the glasshouse (48 spore samplers distributed within the crop at flower height, $1 \mathrm{~m}$ above the ground) and outside the glasshouse (four spore samplers) for 24 h. Afterward, dishes were incubated for 7 days at $20^{\circ} \mathrm{C}$ under fluorescent light. Every month, pure monoconidial cultures were made from five randomly chosen colonies of $B$. cinerea of one sampling date (except for January, when pure monoconidial cultures were made from 10 randomly chosen colonies). Pure cultures (=isolates) were used for pathogenicity assays on gerbera and rose petals.

Conidia of the isolates were stored on porous ceramic beads suspended in a cryopreservative fluid (Protect, STC) at $-20^{\circ} \mathrm{C}$ (20). From stored conidia, cultures were grown by plating beads on potato dextrose agar (PDA) and incubating at $20^{\circ} \mathrm{C}$ under fluorescent light until sporulation.

Germination of conidia. From sporulating cultures, a conidial suspension was made in water, and five droplets of $25 \mu \mathrm{l}$, each containing approximately 125 conidia, were placed on a water agar plate. 
Table 1. Mean percent germination of conidia on water agar and mean percent lesions on gerbera and rose flowers compared with reference isolate Bc16

\begin{tabular}{|c|c|c|c|c|c|}
\hline \multirow[b]{2}{*}{ Isolate } & & \multirow{2}{*}{$\begin{array}{c}\text { Germination }(\%) \\
\text { of conidia on PDA } \\
(n=130)\end{array}$} & \multicolumn{3}{|c|}{ Lesions on flowers compared with isolate Bc16 (\%) } \\
\hline & & & $\begin{array}{c}\text { Gerbera }(n=4) \\
\text { experiment } 1\end{array}$ & $\begin{array}{c}\text { Gerbera }(n=4) \\
\text { experiment } 2\end{array}$ & $\begin{array}{l}\text { Rose } \\
(\mathbf{n}=8)\end{array}$ \\
\hline January1 & $\mathrm{i}^{\mathrm{x}}$ & 92.5 & $52 \mathrm{~b}^{\mathrm{y}}$ & $43 \mathrm{~b}$ & $45 \mathrm{e}$ \\
\hline January2 & $\mathrm{i}$ & 91.6 & $52 \mathrm{bc}$ & & \\
\hline January3 & $\mathrm{i}$ & 67.1 & $68 \mathrm{ab}$ & & \\
\hline January4 & $\mathrm{i}$ & 86.5 & $16 \mathrm{~d}$ & $92^{z} a$ & $100 \mathrm{a}$ \\
\hline January5 & $\mathrm{i}$ & 88.6 & $48 \mathrm{bc}$ & $34 \mathrm{~b}$ & $57 \mathrm{de}$ \\
\hline January6 & $\mathrm{i}$ & 92.3 & $88 \mathrm{a}$ & $72 \mathrm{ab}$ & $95 \mathrm{ab}$ \\
\hline January7 & $\mathrm{i}$ & 81.2 & $28 \mathrm{~cd}$ & $90^{z} \mathrm{a}$ & $83 \mathrm{bc}$ \\
\hline January8 & $\mathrm{i}$ & 80.9 & $48 \mathrm{bc}$ & & \\
\hline January9 & o & 94.4 & $56 \mathrm{~b}$ & $66 \mathrm{ab}$ & $74 \mathrm{~cd}$ \\
\hline January10 & o & 86.3 & $24 \mathrm{~d}$ & $44 \mathrm{~b}$ & $83 \mathrm{bc}$ \\
\hline February1 & $\mathrm{i}$ & 82.2 & $68 \mathrm{ab}$ & & \\
\hline February2 & $\mathrm{i}$ & 67.7 & $36 c$ & & \\
\hline February3 & $\mathrm{i}$ & 80.9 & $36 \mathrm{c}$ & & \\
\hline February4 & $\mathrm{i}$ & 74.2 & $80 \mathrm{a}$ & & \\
\hline February5 & o & 75.1 & $44 \mathrm{bc}$ & & \\
\hline March1 & $\mathrm{i}$ & 63.6 & $80 \mathrm{a}$ & & \\
\hline March2 & $\mathrm{i}$ & 76.4 & $53 \mathrm{bc}$ & $40 \mathrm{a}$ & $94 \mathrm{a}$ \\
\hline March3 & o & 69.6 & $71 \mathrm{ab}$ & & \\
\hline March4 & o & 75.2 & $90 \mathrm{a}$ & $80 \mathrm{a}$ & $103 \mathrm{a}$ \\
\hline March5 & $\mathrm{i}$ & 71.0 & $49 c$ & $65 \mathrm{a}$ & $111 \mathrm{a}$ \\
\hline April1 & $\mathrm{i}$ & 86.2 & $50 \mathrm{bc}$ & $51 \mathrm{ab}$ & $91 \mathrm{a}$ \\
\hline April2 & $\mathrm{i}$ & 84.0 & $30 \mathrm{c}$ & $14 \mathrm{~b}$ & $53 \mathrm{~b}$ \\
\hline April3 & $\mathrm{i}$ & 71.5 & $80 a b c$ & & \\
\hline April4 & $\mathrm{i}$ & 82.5 & $120 \mathrm{a}$ & $76 \mathrm{a}$ & $92 \mathrm{a}$ \\
\hline April5 & o & 77.9 & $90 \mathrm{ab}$ & $66^{z} \mathrm{a}$ & $60 \mathrm{~b}$ \\
\hline May1 & $\mathrm{i}$ & 81.6 & $35 \mathrm{ab}$ & & \\
\hline May2 & $\mathrm{i}$ & 80.4 & $37 \mathrm{a}$ & & \\
\hline May3 & $\mathrm{i}$ & 84.4 & $24 \mathrm{bc}$ & $166^{z} a$ & $65 \mathrm{a}$ \\
\hline May4 & o & 83.0 & $23 \mathrm{bc}$ & $21 \mathrm{~b}$ & $49 \mathrm{a}$ \\
\hline May5 & o & 83.6 & $20 \mathrm{c}$ & $18 \mathrm{~b}$ & $53 \mathrm{a}$ \\
\hline June1 & $\mathrm{i}$ & 96.3 & $90 \mathrm{a}$ & $143 \mathrm{a}$ & $90 \mathrm{~b}$ \\
\hline June2 & $\mathrm{i}$ & 90.3 & $95 \mathrm{a}$ & $58^{\mathrm{z}} \mathrm{b}$ & $119 a$ \\
\hline June3 & $\mathrm{i}$ & 82.0 & $58 \mathrm{~b}$ & $50 \mathrm{~b}$ & $59 \mathrm{c}$ \\
\hline June4 & o & 86.1 & $88 \mathrm{a}$ & $122 \mathrm{a}$ & $63 \mathrm{c}$ \\
\hline June5 & o & 78.7 & $37 \mathrm{~b}$ & & \\
\hline July1 & $\mathrm{i}$ & 86.1 & $37 \mathrm{~b}$ & $28 \mathrm{a}$ & $57 \mathrm{a}$ \\
\hline July2 & $\mathrm{i}$ & 77.7 & $72 \mathrm{a}$ & & \\
\hline July3 & $\mathrm{i}$ & 89.7 & $36 \mathrm{~b}$ & $34 \mathrm{a}$ & $50 \mathrm{a}$ \\
\hline July4 & o & 75.6 & $34 \mathrm{~b}$ & & \\
\hline July5 & o & 91.5 & $47 \mathrm{~b}$ & & \\
\hline August1 & $\mathrm{i}$ & 90.8 & $73 \mathrm{a}$ & & \\
\hline August2 & o & 87.6 & $78 \mathrm{a}$ & & \\
\hline August3 & $\mathrm{i}$ & 79.0 & 108 a & $120 \mathrm{a}$ & $102 \mathrm{a}$ \\
\hline August4 & o & 88.0 & $65 \mathrm{a}$ & $84^{z} b$ & $109 \mathrm{a}$ \\
\hline August5 & $\mathrm{i}$ & 90.2 & $89 a$ & $48^{z} \mathrm{~b}$ & $121 \mathrm{a}$ \\
\hline September1 & $\mathrm{i}$ & 94.1 & $47 \mathrm{~b}$ & & \\
\hline September2 & $\mathrm{i}$ & 98.1 & $42 \mathrm{~b}$ & & \\
\hline September3 & $\mathrm{i}$ & 94.6 & $78 \mathrm{a}$ & & \\
\hline September4 & o & 96.1 & $35 \mathrm{~b}$ & $41 \mathrm{a}$ & $48 \mathrm{a}$ \\
\hline September5 & o & 98.4 & $79 \mathrm{a}$ & & \\
\hline October1 & o & 96.4 & $87 \mathrm{~b}$ & & \\
\hline October2 & $\mathrm{i}$ & 93.0 & $47 \mathrm{c}$ & $67 \mathrm{a}$ & $78 \mathrm{a}$ \\
\hline October3 & $\mathrm{i}$ & 95.5 & $48 \mathrm{c}$ & $52 \mathrm{a}$ & $66 \mathrm{a}$ \\
\hline October4 & o & 96.8 & $148 \mathrm{a}$ & $47^{z} \mathrm{a}$ & $66 \mathrm{a}$ \\
\hline October5 & $\mathrm{i}$ & 92.0 & $80 \mathrm{~b}$ & & \\
\hline November1 & $\mathrm{i}$ & 88.7 & $119 a b$ & & \\
\hline November2 & $\mathrm{i}$ & 92.0 & $111 \mathrm{ab}$ & & \\
\hline November3 & $\mathrm{i}$ & 94.2 & $61 \mathrm{c}$ & & \\
\hline November4 & o & 98.2 & $124 \mathrm{a}$ & & \\
\hline November5 & o & 97.2 & $82 \mathrm{bc}$ & & \\
\hline December1 & $\mathrm{i}$ & 95.7 & $91 \mathrm{bc}$ & & \\
\hline December2 & $\mathrm{i}$ & 95.4 & $65 \mathrm{c}$ & & \\
\hline December3 & $\mathrm{i}$ & 95.5 & $104 \mathrm{ab}$ & & \\
\hline December4 & o & 97.3 & $129 \mathrm{a}$ & & \\
\hline December5 & o & 98.9 & $96 \mathrm{~b}$ & & \\
\hline Bc16 & $\mathrm{i}$ & 90.4 & 100 & 100 & 100 \\
\hline
\end{tabular}

$\mathrm{x} \mathrm{i}=$ trapped inside glasshouse; $\mathrm{o}=$ trapped outside glasshouse.

${ }^{y}$ Mean percent lesions with different letters within 1 month are significantly different $(P \leq 0.05)$. Only the isolates used for DNA analyses were tested in experiment 2 on gerbera flowers and on rose flowers.

${ }^{\mathrm{z}}$ Pathogenicity in experiment 2 differs from that in experiment 1.
Five plates were used per isolate. After 24 $\mathrm{h}$, the percentage of germinated conidia per droplet was counted under a microscope (40x).

Flowers, inoculation, and incubation. Gerbera flowers (cv. Terrafame) were grown on rock wool in a $100 \mathrm{~m}^{2}$ glasshouse. Rose flowers (cv. Sonia) were obtained from a commercial grower (Terra Nigra B.V., Aalsmeer).

For inoculum production, the isolates were grown on PDA under fluorescent light for 7 to 9 days at $20^{\circ} \mathrm{C}$. Conidia were harvested in sterilized distilled water and adjusted to a density of $10^{4}$ conidia per ml. Flowers were inoculated with $1 \mathrm{ml}$ of a conidial suspension in a Potter (14) spray tower, air-dried for $10 \mathrm{~min}$, and incubated in a plastic box $(\mathrm{RH}>95 \%)$. In experiment 1 , each isolate was tested on four gerbera flowers. In experiment 2 , each isolate was tested on four gerbera flowers and on eight rose flowers. Only the isolates used for RAPD analysis were tested in experiment 2 . Between the first and second set of experiments, the conidia of the isolates were stored at $-20^{\circ} \mathrm{C}$, as described above.

For assays on gerbera, the upper 10 petals of each inoculated flower were incubated on wet paper in plastic boxes (RH > 95\%). For assays on rose, whole inoculated flowers were incubated on wet paper in plastic boxes at $20^{\circ} \mathrm{C}$ under fluorescent light (Pope, FTD 36W/30, $8 \mu \mathrm{mol} \cdot \mathrm{m}^{-2} \cdot \mathrm{s}^{-1}$ ). After 1 day of incubation, lesions were counted under a microscope (10x) (16). First stages of successful infection of flowers by $B$. cinerea include germination of conidia, germ tube formation, penetration of the cuticle, and colonization of a few epidermal cells. After $24 \mathrm{~h}$, local necrotic lesions can be recognized as brown spots on the flower surface. Pathogenicity of the isolates was defined as the ability of conidia to induce local lesions and was assessed by counting numbers of necrotic spots per $\mathrm{cm}^{2}$ on the flower. In each experiment, pathogenicity was determined relative to the reference isolate $\mathrm{Bc} 16$ from Salinas et al. (16), which is stable during subculture and after reproduction remains highly pathogenic (10). Numbers of lesions per $\mathrm{cm}^{2}$ were subjected to analysis of variance (ANOVA) using the statistical package GENSTAT 5 (13). LSD values were calculated for comparing the means.

DNA isolation. Conidial suspensions of each isolate, harvested from PDA plates, were grown overnight in potato dextrose broth $(\mathrm{PDB})$ under rotation at $18^{\circ} \mathrm{C}$. The resulting mycelium was collected and freeze-dried. Of each isolate, DNA was extracted from $0.05 \mathrm{~g}$ of mycelium as described by van Kan et al. (18).

RAPD analysis. RAPD analysis was performed as described by Van der VlugtBergmans et al. (17). Primers used in the PCR assays were obtained from Operon Technologies Inc. (RAPD primers B1, B3, B16 and D6, D19 and D20), from Isogen 
Bioscience, Amsterdam (primers X8, X9, and Y20), or from the Department of Molecular Biology, Wageningen Agricultural University (primers R4 and R7).

Data analysis. To estimate the genetic similarity among the isolates, based on the degree of DNA polymorphisms obtained using the primers, similarity coefficients were calculated using Euclidean distances and hierarchical cluster analysis using the single linkage method was performed with the statistical program GENSTAT (13).

\section{RESULTS}

Germination of conidia of the isolates. The germination rate of the conidia on water agar varied from 63.6 to $98.9 \%$ (Table 1). No significant correlation $(P \leq$ 0.05 ) was found between the percentage of germination of the conidia on water agar and the pathogenicity of the isolates.

Pathogenicity of the isolates on gerbera and rose flowers. All isolates produced lesions on gerbera and rose flowers, although to various extents. The relative infection rate (compared with $\mathrm{Bc16}$ ) on gerbera and rose, presented in Table 1, ranged from 14 to $166 \%$. In most cases, the pathogenicity of the isolates varied as much among isolates sampled on the same day of one month as among isolates sampled in different months $(P \leq 0.05)$.

Thirty isolates were tested twice on gerbera (experiments 1 and 2). The pathogenicity of 8 of the 30 isolates differed significantly between the two experiments (Table 1). The pathogenicity of the isolates on rose flowers was overall higher than on gerbera flowers, and the fluctuation in pathogenicity was less than on gerberas, ranging from 45 to $121 \%$ (relative to $\mathrm{Bc} 16)$. Isolates obtained from conidia sampled inside the glasshouse were not more pathogenic than those sampled outside $(P \leq 0.05)$. The mean pathogenicity of isolates sampled in November and December was significantly higher $(P \leq 0.05)$ than that of isolates sampled in January, February, May, July, and September (Table 2).

Table 2. Mean percent lesions on gerbera flowers for different Botrytis cinerea isolates per month of 1992 compared with reference isolate Bc16

\begin{tabular}{lc}
\hline $\mathbf{1 9 9 2}$ & $\begin{array}{c}\text { Mean \% lesions } \\
\text { (experiment 1, n = 20) }\end{array}$ \\
\hline January & $50.4 \mathrm{de}^{\mathrm{z}}$ \\
February & $52.8 \mathrm{c}-\mathrm{e}$ \\
March & $68.6 \mathrm{~b}-\mathrm{d}$ \\
April & $74.0 \mathrm{a}-\mathrm{d}$ \\
May & $27.8 \mathrm{e}$ \\
June & $73.6 \mathrm{a}-\mathrm{d}$ \\
July & $45.2 \mathrm{de}$ \\
August & $82.6 \mathrm{a}-\mathrm{c}$ \\
September & $56.2 \mathrm{c}-\mathrm{e}$ \\
October & $82.0 \mathrm{a}-\mathrm{c}$ \\
November & $99.4 \mathrm{a}$ \\
December & $97.0 \mathrm{ab}$ \\
\hline
\end{tabular}

${ }^{\mathrm{z}}$ Mean percent lesions with different letters are significantly different $(P \leq 0.05)$.

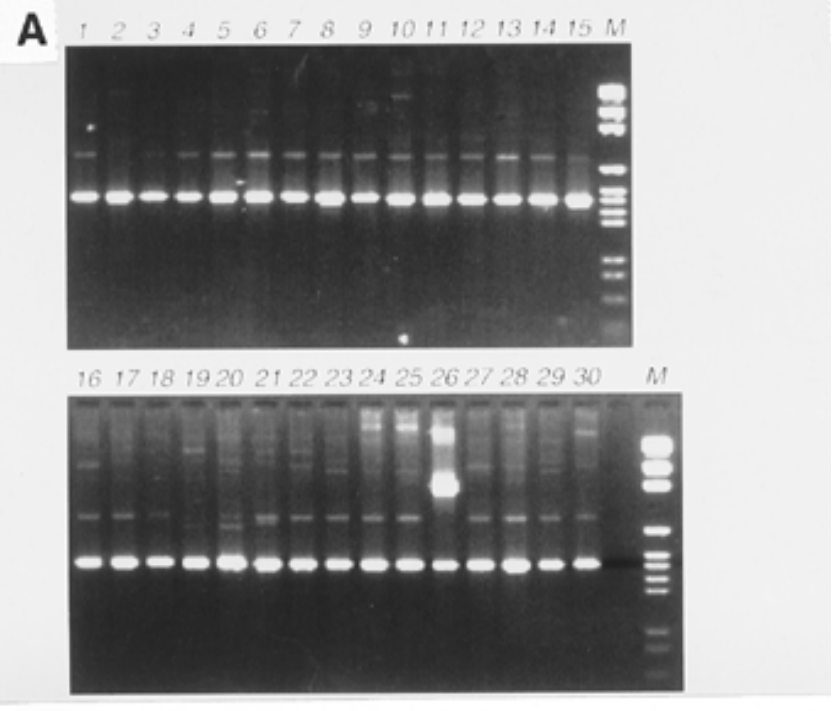

B

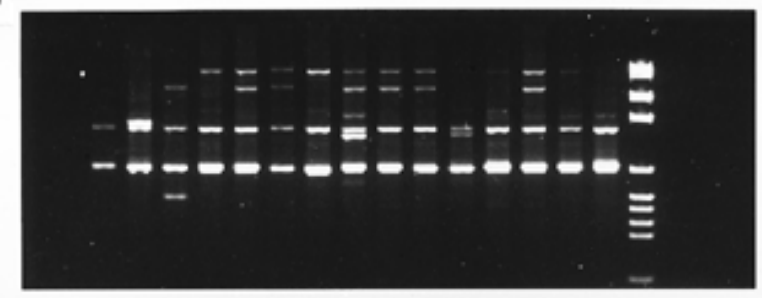

$161718192021222324252627282930 \quad \mathrm{M}$

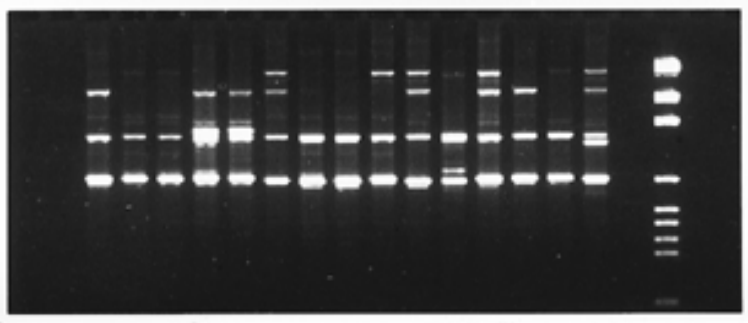

C

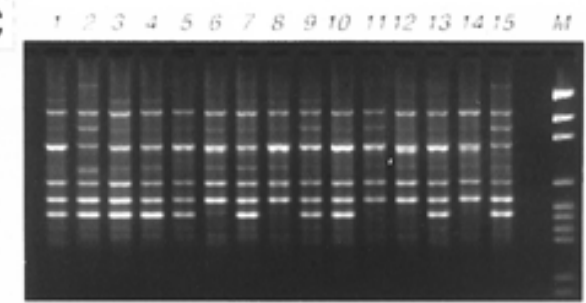

$16171819202122232425262728 \quad 293014$

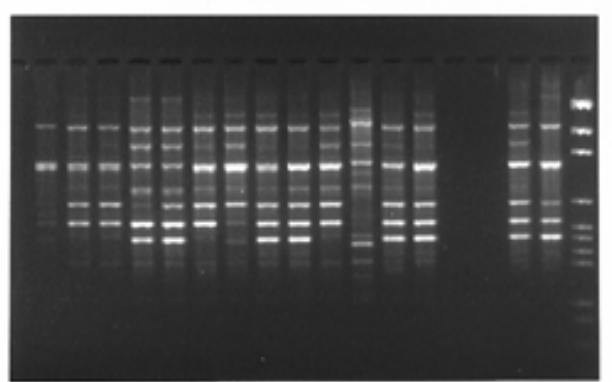

Fig. 1. Random amplified polymorphic DNA (RAPD) profiles of 30 Botrytis cinerea isolates; (A), (B), and (C) universal RAPD-profiles obtained by using primers D6, B1, and B3, respectively. Lanes numbered 1 to 30 represent isolates April4 (=1), April5 (=2), June1 (=3), June2 (=4), August3 (=5), August5 (=6), October4 (=7), January6 (=8), January1 (=9), January9 (=10), October2 (=11), October3 (=12), March5 (=13), April1 (=14), August4 (=15), January4 (=16), January10 (=17), May4 (=18), May5 (=19), July1 (=20), July3 (=21), September4 (=22), April2 (=23), March4 (=24), June4 (=25), January5 (=26), June3 (=27), January7 (=28), May3 $(=29)$, and Bc16 (=30). Lane M shows a PGEM DNA marker. (Sizes of the bands in base pairs from top to bottom are $2645,1605,1198,676,517,460,396,350$, and 222.) 
DNA polymorphisms in isolates of $B$. cinerea. On the basis of pathogenicity experiment 1 , isolates were selected to determine levels of genetic similarity by RAPD analysis. Twenty-nine isolates were chosen, which reflected the entire spectrum of pathogenicity levels, from 16 to $120 \%$ (relative to $\mathrm{Bc16}$ ). Nineteen isolates had been sampled inside and 10 isolates outside the glasshouse. Furthermore, several isolates sampled on the same day of a month were analyzed to examine whether clonal populations were present inside or around the glasshouse. Especially isolates collected from January, March, April, May, June, July, August, and October were examined.

The extent of genetic variation in these 29 isolates and reference strain $\mathrm{Bc} 16$ was studied by RAPD analysis using 11 different primers. All primers generated one to eight amplification products per primer, ranging from 3 to $0.3 \mathrm{~kb}$ in size (Fig. 1), conforming to Van der Vlugt-Bergmans et al. (17). No single primer could be used to distinguish all $B$. cinerea isolates. RAPD analysis with primer D6 yielded a major band of $0.45 \mathrm{kbp}$ in all 30 isolates (Fig. 1A). Isolate January5 contained one additional higher band. The $0.45-\mathrm{kbp}$ band specifically distinguishes $B$. cinerea from other Botrytis species (J. A. L. van Kan, unpublished). On the selective medium of the spore traps, several species of Botrytis were able to grow and change the medium to a dark brown color (8). But all the chosen isolates for RAPD analysis were pathogenic on gerbera and rose flowers, which is typical for $B$. cinerea. Afterward, the unique $0.45-$ kbp band confirmed that all the selected isolates for RAPD analysis were of the species $B$. cinerea. These results indicate that all the 65 fungal isolates sampled are indeed B. cinerea. Other primers, such as B1 and B3, enabled amplification of several fragments on the $B$. cinerea genome, and they revealed polymorphisms among the 30 strains tested (Fig. 1B and C).

To calculate the genetic similarity among the isolates, all 70 RAPD markers obtained with the 11 primers were scored. Table 3 shows the similarity coefficients (SC) for each pair of isolates, which ranged from 0.36 to 1.00 . Isolates April1 and January10 were identical with the primers used. Two other isolates (May4 and October3) were highly similar to the isolates April1 and January10, and to each other $(\mathrm{SC}>97 \%)$. The reference isolate $\mathrm{Bc} 16$ (SC < 0.64) and isolate January5 (SC $<0.49$ ) were genetically quite different from all the other isolates. For the statistical analyses, the isolates January5 and Bc16 were excluded.

The genetic variation among isolates from conidia sampled inside (SC between 0.63 and 0.99 ) or outside (SC between 0.65 and 0.99) the glasshouse was not different from the variation among all isolates (SC between 0.63 and 1.00). The genetic varia- tion among isolates sampled on the same day of one month did not differ from the variation among isolates sampled in different months $(P \leq 0.05)$. The SC within months ranged from 0.70 to 0.94 (January), 0.79 (March), 0.73 to 0.93 (April), 0.65 to 0.77 (May), 0.79 to 0.87 (June), 0.79 (July), 0.80 to 0.84 (August), and 0.67 to 0.89 (October); whereas the SC between months varied from 0.63 (June1 and October2) to 1.00 (January10 and April1).

Cluster analysis. Three groups were distinguished with cluster analysis (Fig. 2): October2, October3, April1, January10, and May4; January5 and Bc16; and April4, April5, June1, June2, August3, August5, October4, January6, January1, January9, March5, August4, January4, May5, July1, July3, September4, April2, March4, June4, June3, January7, and May3.

With the cluster analyses used, no relation between group and pathogenicity, between group and sampling month, and between group and sampling situation (inside or outside the glasshouse) could be found (Tables 1 and 3). Nevertheless, the groups distinguished are based on genetic similarity.

\section{DISCUSSION}

The pathogenicity of isolates of $B$. cinerea sampled in a rose glasshouse in 1992 (compared with a reference isolate, $\mathrm{Bc16}$ ) showed considerable variation. However, all isolates obtained from conidia sampled

Table 3. Similarity coefficients (using Euclidean distances) for all pairs of isolates of Botrytis cinerea calculated by GENSTAT 5 (13)

$1^{\mathrm{z}} \quad 0.00$

20.790 .00

$\begin{array}{lllll}3 & 0.90 & 0.74 & 0.00\end{array}$

$4 \quad 0.83 \quad 0.700 .810 .00$

$\begin{array}{lllllll}5 & 0.91 & 0.79 & 0.93 & 0.86 & 0.00\end{array}$

$\begin{array}{llllllll}6 & 0.87 & 0.74 & 0.83 & 0.79 & 0.84 & 0.00\end{array}$

$\begin{array}{lllllllll}7 & 0.83 & 0.79 & 0.84 & 0.91 & 0.89 & 0.79 & 0.00\end{array}$

$\begin{array}{llllllllllll}8 & 0.80 & 0.76 & 0.76 & 0.74 & 0.83 & 0.84 & 0.74 & 0.00\end{array}$

$\begin{array}{llllllllllllll}9 & 0.84 & 0.74 & 0.89 & 0.84 & 0.87 & 0.80 & 0.87 & 0.79 & 0.00\end{array}$

$\begin{array}{llllllllllllll}10 & 0.83 & 0.76 & 0.84 & 0.86 & 0.91 & 0.79 & 0.89 & 0.80 & 0.87 & 0.00\end{array}$

$\begin{array}{llllllllllll}11 & 0.70 & 0.71 & 0.63 & 0.67 & 0.67 & 0.69 & 0.67 & 0.73 & 0.66 & 0.73 & 0.00\end{array}$

$\begin{array}{llllllllllllllll}12 & 0.76 & 0.71 & 0.66 & 0.73 & 0.73 & 0.74 & 0.70 & 0.73 & 0.69 & 0.70 & 0.89 & 0.00\end{array}$

$\begin{array}{lllllllllllllll}13 & 0.87 & 0.74 & 0.86 & 0.87 & 0.87 & 0.91 & 0.87 & 0.79 & 0.89 & 0.87 & 0.69 & 0.74 & 0.00\end{array}$

$\begin{array}{lllllllllllllllllll}14 & 0.77 & 0.73 & 0.67 & 0.74 & 0.74 & 0.76 & 0.71 & 0.74 & 0.70 & 0.71 & 0.90 & 0.99 & 0.76 & 0.00\end{array}$

$\begin{array}{lllllllllllllllll}15 & 0.84 & 0.91 & 0.80 & 0.73 & 0.84 & 0.80 & 0.79 & 0.84 & 0.74 & 0.79 & 0.71 & 0.71 & 0.77 & 0.73 & 0.00\end{array}$

$\begin{array}{llllllllllllllllllll}16 & 0.89 & 0.76 & 0.90 & 0.86 & 0.91 & 0.81 & 0.86 & 0.77 & 0.87 & 0.89 & 0.67 & 0.70 & 0.90 & 0.71 & 0.79 & 0.00\end{array}$

$\begin{array}{llllllllllllllllllll}17 & 0.77 & 0.73 & 0.67 & 0.74 & 0.74 & 0.76 & 0.71 & 0.74 & 0.70 & 0.71 & 0.90 & 0.99 & 0.76 & 1.00 & 0.73 & 0.71 & 0.00\end{array}$

$\begin{array}{llllllllllllllllllll}18 & 0.76 & 0.71 & 0.66 & 0.73 & 0.73 & 0.74 & 0.70 & 0.73 & 0.69 & 0.70 & 0.89 & 0.97 & 0.74 & 0.99 & 0.71 & 0.70 & 0.99 & 0.00\end{array}$

$\begin{array}{llllllllllllllllllllllll}19 & 0.74 & 0.86 & 0.73 & 0.71 & 0.77 & 0.73 & 0.77 & 0.80 & 0.70 & 0.77 & 0.71 & 0.68 & 0.73 & 0.67 & 0.86 & 0.74 & 0.67 & 0.65 & 0.00\end{array}$

$\begin{array}{llllllllllllllllllllll}20 & 0.81 & 0.89 & 0.77 & 0.79 & 0.81 & 0.77 & 0.79 & 0.81 & 0.77 & 0.76 & 0.69 & 0.71 & 0.77 & 0.73 & 0.89 & 0.79 & 0.73 & 0.71 & 0.92 & 0.00\end{array}$

$\begin{array}{llllllllllllllllllllllllllll}21 & 0.80 & 0.76 & 0.76 & 0.77 & 0.80 & 0.87 & 0.77 & 0.83 & 0.79 & 0.80 & 0.76 & 0.81 & 0.87 & 0.83 & 0.79 & 0.80 & 0.83 & 0.81 & 0.73 & 0.79 & 0.00\end{array}$

$\begin{array}{lllllllllllllllllllllllll}22 & 0.89 & 0.81 & 0.84 & 0.86 & 0.89 & 0.76 & 0.89 & 0.80 & 0.87 & 0.86 & 0.70 & 0.73 & 0.84 & 0.74 & 0.81 & 0.89 & 0.74 & 0.73 & 0.74 & 0.81 & 0.80 & 0.00\end{array}$

$\begin{array}{llllllllllllllllllllllll}23 & 0.93 & 0.80 & 0.86 & 0.87 & 0.90 & 0.83 & 0.84 & 0.79 & 0.86 & 0.87 & 0.74 & 0.74 & 0.86 & 0.76 & 0.83 & 0.90 & 0.76 & 0.74 & 0.76 & 0.83 & 0.76 & 0.90 & 0.00\end{array}$

$\begin{array}{lllllllllllllllllllllllllllllllll}24 & 0.87 & 0.76 & 0.81 & 0.86 & 0.87 & 0.78 & 0.84 & 0.75 & 0.83 & 0.87 & 0.75 & 0.76 & 0.79 & 0.76 & 0.81 & 0.79 & 0.76 & 0.78 & 0.75 & 0.81 & 0.78 & 0.83 & 0.91 & 0.00\end{array}$

$\begin{array}{lllllllllllllllllllllllllllllll}25 & 0.80 & 0.76 & 0.79 & 0.83 & 0.86 & 0.87 & 0.80 & 0.91 & 0.81 & 0.83 & 0.70 & 0.76 & 0.87 & 0.77 & 0.81 & 0.86 & 0.77 & 0.76 & 0.74 & 0.81 & 0.89 & 0.86 & 0.84 & 0.76 & 0.00\end{array}$

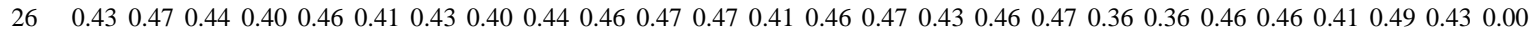

$\begin{array}{lllllllllllllllllllllllllllllllllllllll}27 & 0.87 & 0.77 & 0.86 & 0.84 & 0.93 & 0.83 & 0.90 & 0.81 & 0.86 & 0.93 & 0.69 & 0.74 & 0.91 & 0.76 & 0.83 & 0.90 & 0.76 & 0.74 & 0.76 & 0.77 & 0.84 & 0.87 & 0.86 & 0.83 & 0.87 & 0.44 & 0.00\end{array}$

$\begin{array}{llllllllllllllllllllllllllllll}28 & 0.91 & 0.76 & 0.93 & 0.83 & 0.94 & 0.81 & 0.86 & 0.80 & 0.90 & 0.91 & 0.70 & 0.70 & 0.87 & 0.71 & 0.81 & 0.94 & 0.71 & 0.70 & 0.74 & 0.79 & 0.80 & 0.89 & 0.90 & 0.84 & 0.83 & 0.46 & 0.90 & 0.00\end{array}$

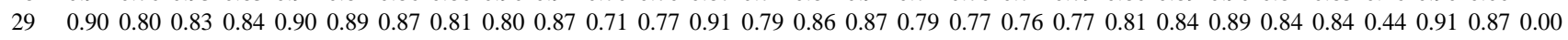

$\begin{array}{lllllllllllllllllllllllllllllllllllllllllll}30 & 0.55 & 0.55 & 0.50 & 0.48 & 0.52 & 0.64 & 0.52 & 0.62 & 0.57 & 0.48 & 0.52 & 0.48 & 0.57 & 0.50 & 0.62 & 0.48 & 0.50 & 0.52 & 0.50 & 0.52 & 0.53 & 0.53 & 0.57 & 0.53 & 0.59 & 0.57 & 0.50 & 0.52 & 0.57 & 0.00\end{array}$ $\begin{array}{lllllllllllllllllllllllllllllllll}1 & 2 & 3 & 4 & 5 & 6 & 7 & 8 & 9 & 10 & 11 & 12 & 13 & 14 & 15 & 16 & 17 & 18 & 19 & 20 & 21 & 22 & 23 & 24 & 25 & 26 & 27 & 28 & 29 & 30\end{array}$

\footnotetext{
${ }^{\mathrm{z}}$ Numbers 1 to 30 represent isolate April4 (=1), April5 (=2), June1 (=3), June2 (=4), August3 (=5), August5 (=6), October4 (=7), January6 (=8), January1 (=9), January9 (=10), October2 (=11), October3 (=12), March5 (=13), April1 (=14), August4 (=15), January4 (=16), January10 (=17), May4 (=18), May5 (=19), July1 (=20), July3 (=21), September4 (=22), April2 (=23), March4 (=24), June4 (=25), January5 (=26), June3 (=27), January7 (=28), May3 (=29), and $\mathrm{Bc} 16(=30)$.
} 
in the glasshouse were to a certain extent able to cause lesions on flowers at a relative humidity $>95 \%$. With the pathogenicity test used in the present study, the relative ability to form lesions can be estimated reasonably well. The pathogenicity of isolates on gerbera flowers in experiment 1 sometimes differed from the pathogenicity in experiment 2. Monoconidial pure isolates were stored frozen before they were plated and used in experiment 2. Possibly some of these monoconidial cultures are unstable due to heterokaryosis $(1,6)$ or due to intrinsic genetic instability, in which transposons of $B$. cinerea may play a role (4).

The variability in pathogenicity among isolates could not be attributed to the quality of conidia, since there was no significant correlation to the ability of the conidia to germinate on water agar. According to Salinas et al. (16) and A. Kerssies (unpublished results), every conidium germinating on the surface of a gerbera petal is able to penetrate and induce a lesion. Differences in relative pathogenicity among the isolates are thus apparently caused by a variability in successful germination of $B$. cinerea conidia on the flower surface, resulting in a variable number of necrotic lesions. Variability in pathogenicity was found in isolates sampled at 12 days throughout the year and in all the seasons, and is probably not accounted for by climatic factors, because no significant correlation was found between season and pathogenicity.

Only one rose cultivar, very susceptible to B. cinerea, was grown during the sampling in 1992. The variability, both genetic and in pathogenicity, probably reflects the ubiquitous presence of $B$. cinerea conidia, regularly distributed within the glasshouse, from numerous sources outside glasshouses. In glasshouses with a dry production system, as in the rose glasshouse, sporulating spots of different sources (e.g., strawberries, ornamentals) outside the glasshouse may be the important sources for $B$. cinerea conidia (10). Inside this glasshouse, no sporulating sources were detected and no epidemic of $B$. cinerea was observed in 1992 (11). Therefore, we expected that the genetic population structure of isolates sampled in and around the glasshouse would be a reflection of sources outside the glasshouse. It was the aim of the RAPD analysis to investigate this matter in more detail. The 29 isolates that were subjected to RAPD analysis were selected on several criteria: isolates that were sampled on the same day (in 6 different months) were analyzed to detect clonal epidemics on a particular day; isolates sampled inside or outside the glasshouse

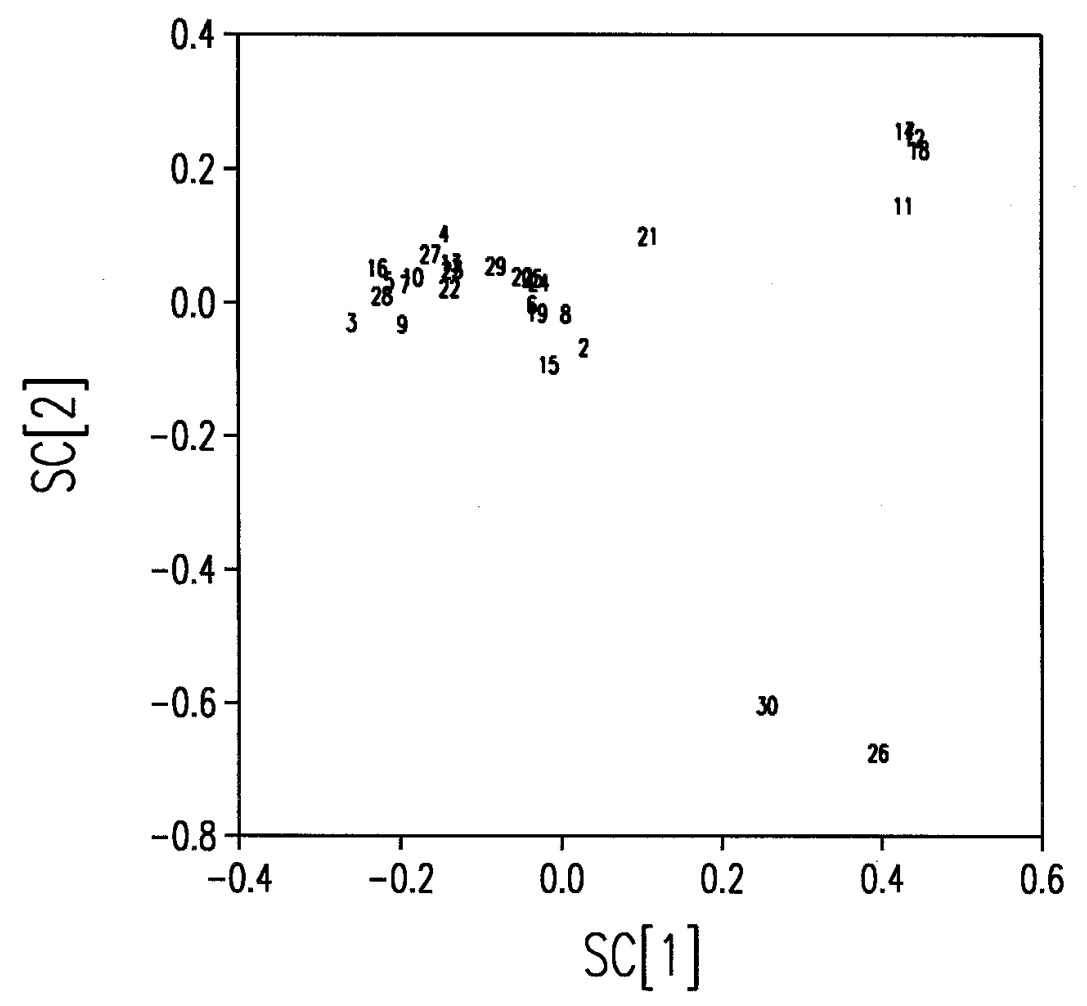

Fig. 2. Clusters calculated with hierarchical cluster analysis using the single linkage method according to the statistical program GENSTAT 5 (13). The first and second dimensions are shown. SC = similarity coefficient. Numbers 1 to 30 represent isolates April4 (=1), April5 (=2), June1 (=3), June2 $(=4)$, August3 (=5), August5 (=6), October4 (=7), January6 (=8), January1 (=9), January9 $(=10)$, October2 (=11), October3 (=12), March5 (=13), April1 (=14), August4 (=15), January4 (=16), January10 (=17), May4 (=18), May5 (=19), July1 (=20), July3 (=21), September4 (=22), April2 (=23), March4 (=24), June4 (=25), January5 (=26), June3 (=27), January7 (=28), May3 (=29), and Bc16 $(=30)$. were analyzed; isolates with different relative pathogenicity levels were analyzed to investigate whether similar pathogenicity levels reflect genetic similarities.

RAPD profiles obtained with primer D6 showed that all isolates sampled inside and outside the rose glasshouse originated from conidia of $B$. cinerea. This may be a confirmation of the selectivity of the medium developed by Kerssies (8), but it might also indicate that there were no sources of conidia of other Botrytis species in the vicinity of the glasshouse.

Analysis with other RAPD primers revealed that, with few exceptions, almost all of the isolates tested were genetically different. No relation was found between relative pathogenicity levels and RAPD patterns. Furthermore, no relation was found between RAPD patterns and the origin of isolates (outside or inside the glasshouse), or between RAPD patterns and the month of sampling. The biological or genetic meaning of the different groups distinguished with cluster analysis is unknown. Probably different sporulating sources are responsible for the different groups.

Isolates April1 (sampled inside the glasshouse) and January10 (sampled outside the glasshouse) were identical with all the primers used. In experiment 2, these two isolates showed significantly similar relative infection rates $(P \leq 0.05)$ on both rose and gerbera (Table 1). This finding suggests that a source was present outside the glasshouse in January that produced the conidium later trapped inside the glasshouse, resulting in isolate April1. Although a more extensive molecular analysis might reveal minor differences between the two isolates, it may be speculated that these two isolates originated from the same primary source. Two other isolates (May4 and October3, SC > 0.97) were highly similar to the two isolates April1 and January10, and to each other. Isolate May4 was sampled outside and October3 inside the glasshouse. Although they differ in only two RAPD fragments (out of 70 fragments detected), it is possible that these two isolates originate from the same primary source, but that a mutation during propagation in the season resulted in the change of RAPD profile.

Our results further confirm the earlier findings (10) that the inoculum source in glasshouses is ubiquitous and very heterogeneous with respect to relative pathogenicity and genetic background. There is a constant flux of conidia into and out of the glasshouse throughout the season.

\section{ACKNOWLEDGMENTS}

We thank M. J. Jeger, J. C. Zadoks, and H. D. Frinking for critically reading the manuscript, and $\mathrm{J}$. Benninga for helping with the statistical analyses.

\section{LITERATURE CITED}

1. Akutsu, K., Tsukamoto, T., Irino, T., and Okuyama, S. 1988. Transfer of benomyl-resistance by hyphal fusion of Botrytis cinerea. 
Ann. Phytopathol. Soc. Jpn. 54:309-316.

2. Blakeman, J. P. 1980. Behaviour of conidia on aerial plant surfaces. Pages 115-151 in: The Biology of Botrytis. J. R. Coley-Smith, K. Verhoeff, and W. R. Jarvis, eds. Academic Press, London.

3. De Jong, J. T. 1986. Grauwe schimmel de grootste schadeveroorzaker. Vakblad Bloemisterij 31:12-13.

4. Diolez, A., Marches, F., Fortini, D., and Brygoo, Y. 1995. Boty, a long-terminal-repeat retroelement in the phytopathogenic fungus Botrytis cinerea. Appl. Environ. Microbiol. 61:103-108.

5. Elad, Y., Kirshner, B., and Gotlib, Y. 1993. Attempts to control Botrytis cinerea on roses by pre- and postharvest treatments with biological and chemical agents. Crop Prot. 12:69-73.

6. Grindle, M. 1979. Phenotypic differences between natural and induced variants of $\mathrm{Bo}$ trytis cinerea. J. Gen. Microbiol. 111:109120.

7. Jarvis, W. R. 1980. Epidemiology. Pages 219250 in: The Biology of Botrytis. J. R. ColeySmith., K. Verhoeff, and W. R. Jarvis, eds. Academic Press, London.

8. Kerssies, A. 1990. A selective medium to be used in a spore-trap. Neth. J. Plant Pathol.
96:247-250.

9. Kerssies, A. 1993. Horizontal and vertical distribution of Botrytis cinerea in a gerbera crop grown under glass. Neth. J. Plant Pathol. 99:303-311.

10. Kerssies, A. 1994. Epidemiology of Botrytis spotting on gerbera and rose flowers grown under glass. Ph.D. thesis. Wageningen Agricultural University, Wageningen. $133 \mathrm{pp}$.

11. Kerssies, A., Bosker-van Zessen, A. I., and Frinking, H. D. 1995. Influence of environmental conditions in a glasshouse on conidia of Botrytis cinerea and on post-harvest infection of rose flowers. Eur. J. Plant Pathol. 101:201-216.

12. Paddy, S. M., and Kelly, C. D. 1954. Aerobiological studies of fungi and bacteria over the Atlantic Ocean. Can. J. Bot. 32:202-212.

13. Payne, R. W., Lane, P. W., Ainsley, A. E., Gower, J. C., Tunnicliffe-Wilson, G., and Paterson, L. J. 1987. GENSTAT 5: Reference Manual. Clarendon Oxford GB Oxford, Science Publications.

14. Potter, C. 1952. An improved laboratory apparatus for applying direct sprays and surface films, with data on the electrostatic charge on atomized spray fluids. Ann. Appl. Biol. 39:1-28.

15. Richards, M. 1956. A census of mould spores in the air over Britain in 1952. Trans. Br. Mycol. Soc. 39:431-441.

16. Salinas, J., Glandorf, D. C. M., Picavet, F. D. and Verhoeff, K. 1989. Effects of temperature, relative humidity and age of conidia on the incidence of spotting on gerbera flowers caused by Botrytis cinerea. Neth. J. Plant Pathol. 95:51-64.

17. Van der Vlugt-Bergmans, C. J. B., Brandwagt, B. F., van't Klooster, J. W., Wagemakers, C. A. M., and van Kan, J. A. L. 1993. Genetic variation and segregation of DNA polymorphisms in Botrytis cinerea. Mycol. Res. 97:1193-1200.

18. van Kan, J. A. L., van den Ackerveken, G. F. J. M., and De Wit, P. J. G. M. 1991. Cloning and characterization of cDNA of the avirulence gene $a v r 9$ of the fungal pathogen $\mathrm{Cla}$ dosporium fulvum, the causal agent of tomato leaf mould. Mol. Plant-Microbe Interact. 4:52-59.

19. Verhoeff, K. 1980. The infection process and host-pathogen interactions. Pages 153-180 in: The Biology of Botrytis. J. R. Coley-Smith, K. Verhoeff, and W. R. Jarvis, eds. Academic Press, London.

20. White, D. J., and Sands, R. L. 1985. Storage of bacteria at $-76^{\circ} \mathrm{C}$. Med. Lab. Sci. 42:289 290. 